\title{
PASIVITAS FUNGSI ADVOKAT DALAM PROSES PRA-ADJUDIKASI: MEMBONGKAR TINDAKAN KOMUNIKATIF INSTRUMENTAL PENYIDIK
}

\author{
Rocky Marbun \\ Fakultas Hukum Universitas Pancasila, Jakarta \\ Jl. Buku Dikrama No.30, RT.5/RW.5, Srengseng Sawah, Kec. Jagakarsa, Kota Jakarta \\ Selatan, Daerah Khusus Ibukota Jakarta 12630 \\ rocky_marbun@univpancasila.ac.id
}

\begin{abstract}
The examination process in the investigation of Suspects and Witnesses is always in the form of Minutes of Investigation as a legal product. Based on Article 117 paragraph (2) of the Criminal Procedure Code, the Investigator should pour the information obtained through speech acts without any attempt to re-suspect the suspect or witness. To maintain the condition of intersubjective communication, the Criminal Procedure Code gives the suspect the right to obtain legal assistance since the investigation process. However, based on Article 115 paragraph (1) of the Criminal Procedure Code, the assistance function is passive. Therefore, the researcher proposes the formulation of the problem is "How should the advocacy model by the Advocate as the Legal Counsel accompany the Client in the investigation process?" In this study, researchers used the Normative J uridical Method based on secondary data. As for completing the research method, the researcher also uses several research approaches, including the philosophical approach, conceptual approach, and linguistic approach. The result of this research is to place an Advocate's position equally with the Investigator through the elimination of the phrase in Article 115 paragraph (1) of the Criminal Procedure Code to realize the protection of Human Rights from being examined.
\end{abstract}

Keywords: Advocates, Investigation, Communications, Instrumental, Criminal Procedure.

\begin{abstract}
Abstrak, Proses pemeriksaan dalam penyidikan terhadap Tersangka dan Saksi selalu berbentuk Berita Acara Pemeriksaan (BAP) sebagai produk hukum yang sah. Berdasarkan Pasal 117 ayat (2) KUHAP, Penyidik memiliki kewajiban untuk menuangkan keterangan yang diperoleh melalui tindak tuturan tanpa adanya upaya reifikasi terhadap Tersangka atau Saksi. Guna menjaga kondisi komunikasi intersubjektif tersebut, KUHAP memberikan hak bagi Tersangka untuk mendapatkan bantuan hukum semenjak proses penyidikan. Namun demikian, berdasarkan Pasal 115 ayat (1) KUHAP, fungsi pendampingan tersebut bersifat pasif. Oleh karena itu, Peneliti mengajukan rumusan masalah "Bagaimanakah seharusnya model pendampingan oleh Advokat sebagai Kuasa Hukum dalam mendampingi Kliennya pada proses penyidikan?" Pada penelitian ini, Peneliti menggunakan Metode Yuridis Normatif yang berbasis kepada data sekunder. Adapun untuk melengkapi metode penelitian tersebut, Peneliti pula menggunakan beberapa pendekatan penelitian antara lain pendekatan filsafat, pendekatan konseptual, dan pendekatan linguistik. Adapun hasil dari penelitian ini adalah menempatkan posisi Advokat secara setara dengan Penyidik melalui penghapusan frasa dalam Pasal 115 ayat (1) KUHAP guna mewujudkan perlindungan Hak Asasi Manusia dari terperiksa.
\end{abstract}

Kata Kunci: Advokat, Penyidikan, Komunikasi, Instrumental, Acara Pidana. 


\section{Pendahuluan}

Gagasan atau ide mengenai asas negara hukum yang dieksternalisasi melalui proses normativisasi dalam KUHAP, telah menciptakan suatu jargoon yang dilekatkan kepada KUHAP sebagai suatu karya yang 'sublim'. Semenjak tahun 1981, melalui proses hegemoni (persuasif) dalam berbagai pola pengajaran dan pendidikan pada fakultasfakultas hukum, hingga hari ini telah menjadi suatu 'mitos' bahwa KUHAP merupakan karya besar bangsa Indonesia. ${ }^{1}$

Keagungan tersebut mendapatkan legitimasi filosofisnya sebagai suatu upaya dekolonialisasi terhadap paradigma-paradigma yang hidup dan berkembang secara dominasi oleh Belanda pada era kolonialisme di Indonesia yang diatur dalam HIR (het herziene indlandsche/indonesisch reglement) atau disebut juga RIB (Reglemen Indonesia yang Dibaharui) (Stb.1848 No. 16, Stb. 1941 No. 44) dan Rbg. (rechtreglement buitengewesten) atau disebut juga reglement untuk daerah seberang (Stb.1927 No. 227).

Landasan filosofis yang memberikan legitimasi dalam upaya dekolonialisasi tersebut sebagaimana tertuang dalam Konsideran Menimbang huruf a KUHAP yang menegaskan "bahwa negara Republik Indonesia adalah negara hukum berdasarkan Pancasila dan Undang-Undang Dasar 1945 yang menjunjung tinggi hak asasi manusia serta yang menjamin segala warga negara bersamaan kedudukannya di dalam hukum dan pemerintahan dan wajib menjunjung hukum dan pemerintahan itu dengan tidak ada kecualinya." Artinya, Indonesia telah menggesar dominasi tersebut dengan mengakui dan mengakomodir asas negara hukum dengan variannya berdasarkan Pancasila dan UndangUndang Dasar Negara Republik Indonesia Tahun 1945 (UUD NRI 1945).

Hal tersebut merupakan konsekuensi logis sebagai amanah dari Penjelasan Umum UUD 1945 (pra-amandemen) yang menegaskan "Indonesia ialah negara yang berdasar atas hukum (rechtsstaat)". ${ }^{2}$ Maka, berlakulah prinsip-prinsip dasar dari asas negara hukum—sebagaimana dikemukakan oleh FJ. Stahl, yaitu sebagai berikut: ${ }^{3}$

1. Berdasarkan hak-hak asasi;

2. Untuk melindungi hak-hak asasi dengan baik harus ada pemisahan kekuasaan (trias politica);

3. Pemerintahannya harus berdasarkan undang-undang/Hukum; dan

\footnotetext{
${ }^{1}$ Pada umumnya, dalam berbagai tulisan ilmiah menjelaskan KUHAP sebagai 'karya agung' sebagai jargoon. Lihat: Nike K. Rumokoy, Eksistensi Afdoening Buiten Process Dalam Hukum Acara Pidana Indonesia, Jurnal Hukum Unsrat, Vol. 23, No. 8, Januari 2017, hlm. 47.; Lihat: Umi Falasifah, Bambang Dwi Baskoro, dan Sukinta, Tinjauan Tentang Pembaharuan KUHAP Sebagai Landasan Bekerjanya Sistem Peradilan Pidana di Indonesia, Diponegoro Law Journal, Vol. 5, No. 3, 2016, hlm. 2; Lihat: Andi Sofyan, Hukum Acara Pidana. Suatu Pengantar, (Yogyakarta: Rangkang Education, 2012), hlm. 52.

${ }^{2}$ Pada Amandemen ketiga pada tanggal 9 November 2001 ditarik ke dalam batang tubuh menjadi Pasal 1 ayat (3) UUD NRI 1945 yang menegaskan "Negara Indonesia adalah negara hukum."

${ }^{3}$ Padmo Wahyono, Membudayakan Undang-Undang Dasar 1945, (Jakarta: Ind-HILL.co, 1991), hlm. 73 .
} 
4. Apabila dalam perlindungan hak asasi dengan berdasarkan undang-undang masih ada pelanggaran hak asasi maka perlu ada peradilan administrasi.

Berdasarkan hal tersebut di atas, maka negara memiliki dua jenis kebijakan, yaitu kebijakan kehidupan sosial dan kebijakan kehidupan bernegara.Adapun yang dimaksud dengan penyelenggaraan kehidupan bernegara ialah bidang yang bersangkut paut dengan kelangsungan hidup organisasi negara, yang meliputi pembentukan mekanisme perundang-undangan sebagai kelanjutan dari hukum dasar tertulis dan tidak tertulis, menyelidiki pasal-pasalnya, bagaimana penerapannya, suasana kebatinannya, perumusan teks perundang-undangan, suasana terciptanya teks perundang-undangan tersebut, keterangan-keterangan berkaitan proses pembentukannya, dimana kesemuanya berkaitan dengan pengaturan yang terdapat di dalam konstitusi mengenai organisasi kenegaraan. Dalam bidang ini, perlu dicatat beberapa tahap pelaksanaan ketentuan-ketentuan mengenai organisasi negara yang dipengaruhi oleh keadaan dan waktu. ${ }^{4}$

Dengan demikian, dalam kaitannya dengan bekerjanya organ pemerintahan yang memiliki fungsi penegakan hukum, hendaknya mampu mengeksternalisasikan asas negara hukum tersebut dengan mengacu kepada prinsip-prinsip penghormatan terhadap Hak Asasi Manusia dan asas equality before the law (persamaan kedudukan di depan hukum). Sehingga, politik hukum yang terkandung dalam KUHAP tertuang dalam Konsideran Menimbang huruf c KUHAP yang menegaskan "bahwa pembangunan hukum nasional yang demikian itu di bidang hukum acara pidana adalah agar masyarakat menghayati hak dan kewajibannya dan untuk meningkatkan pembinaan sikap para pelaksana penegak hukum sesuai dengan fungsi dan wewenang masing-masing ke arah tegaknya hukum, keadilan dan perlindungan terhadap harkat dan martabat manusia, ketertiban serta kepastian hukum demi terselenggaranya negara hukum sesuai dengan Undang-Undang Dasar 1945."

Sehingga, tujuan dari politik hukum pembentukan KUHAP adalah sebagai berikut:

1. Agar masyarakat menghayati hak dan kewajibannya;

2. Untuk meningkatkan pembinaan sikap para pelaksana penegak hukum sesuai dengan fungsi dan wewenang masing-masing; dan

3. Tegaknya hukum, keadilan dan perlindungan terhadap harkat dan martabat manusia, ketertiban serta kepastian hukum

Berkaitan dengan point No. (2) dan (3), tentunya mengingatkan kita kepada doktrin dari Roeslan Saleh, bahwa persoalan yang lebih penting adalah mengenai cara-cara bagaimanakah hukum pidana itu diterapkan. Hukum itu berdasarkan ketentuan undangundangnya dikonkritkan dalam hubungan yang bersifat antar manusia yaitu dari mereka yang telah melakukan perbuatan pidana dan mereka yang berurusan dengan persoalan ini dalam tingkat-tingkat dari peradilan pidana. Sifat dari hubungan ini kerapkali mempunyai

${ }^{4}$ Padmo Wahyono, Indonesia Negara Berdasarkan Atas Hukum, (Jakarta: Ghalia Indonesia, 1986), hlm. 17-18. 
arti menentukan terhadap cara bagaimana mereka yang telah melakukan perbuatan itu akan mengalami tentang penerapan hukum pidana. ${ }^{5}$

Distilasi dari landasan politik hukum dalam Konsideran huruf c KUHAP tersebut—dalam kaitannya dengan perlindungan Hak Asasi Manusia (HAM) bagi Saksi dan Tersangka dalam proses pemeriksaan pada tingkat Penyidikan, tertuang dalam Pasal 52 KUHAP jo Pasal 117 KUHAP. Dimana pada Pasal 52 KUHAP menegaskan "Dalam pemeriksaan pada tingkat penyidikan dan pengadilan, tersangka atau terdakwa berhak memberikan keterangan secara bebas kepada penyidik atau hakim."

Lebih lanjut, ditentukan dalam Pasal 117 KUHAP sebagai berikut:

(1) Keterangan tersangka dan atau saksi kepada penyidik diberikan tanpa tekanan dari siapa pun dan atau dalam bentuk apapun;

(2) Dalam hal tersangka memberi keterangan tentang apa yang sebenarnya ia telah lakukan sehubungan dengan tindak pidana yang dipersangkakan kepadanya, penyidik mencatat dalam berita acara seteliti-telitinya sesuai dengan kata yang dipergunakan oleh tersangka sendiri.

Berdasarkan ketentuan tersebut di atas, maka patut dicermati mengenai output dari proses Penyidikan yaitu berupa Berita Acara Pemeriksaan, sebagaimana tertuang dalam Pasal 118 ayat (1) KUHAP yang menegaskan "Keterangan tersangka dan atau saksi dicatat dalam berita acara yang ditandatangani oleh penyidik dan oleh yang memberi keterangan itu setelah mereka menyetujui isinya."

Dengan demikian, pemerolehan keterangan dari seorang tersangka dan saksi hanya dimungkinkan dari suatu peristiwa sebagai tindak tuturan (speech-act) atau dapat pula dikenal dengan istilah peristiwa tuturan, yaitu terjadinya atau berlangsungnya interaksi linguistik dalam satu bentuk ujaran atau lebih yang melibatkan dua pihak, yaitu penutur dan lawan tutur, dengan satu pokok tuturan, di dalam waktu, tempat, dan situasi tertentu. ${ }^{6}$ Sehingga, antara Penyidik sebagai Pemeriksa dan Saksi/Tersangka sebagai Terperiksa seahrusnya akan saling bertukar fungsi secara seimbang baik sebagai komunikan (penerima pesan) maupun sebagai komunikator (pengirim pesan).

Namun demikian, berdasarkan kajian dari Sri Waljinah terhadap proses penyidikan tersebut, yang terjadi adalah suatu proses komunikasi dengan logika monologinstrumentalis. Dimana, seseorang yang menjalani proses pemeriksaan, telah dengan secara sengaja diletakan sebagai subyek yang diobjektivikasikan (reifikasi) melalui proses komunikasi instrumental, yang ditujukan hanya sebagai proses pemerolehan bahan keterangan semata. ${ }^{7}$ Sehingga, peristiwa tuturan dalam komunikasi antara Penyidik dengan Terperiksa menjadi suatu momentum bagi Penyidik untuk mengkonfirmasi praanggapan yang sudah ada dalam diri Penyidik tersebut.

${ }^{5}$ Roeslan Saleh, Mengadili Sebagai Pergulatan Kemanusiaan, (Jakarta: Aksara Baru, 1983), hlm. 14-16.

${ }^{6}$ Abdul Chaer dan Leonie Agustina, Sosiolingugistik, (Jakarta: Rineka Cipta, 2010), hlm. 47.

${ }^{7}$ Sri Waljinah, Linguistik Forensik Interogasi: Kajian Makna Simbolik Bahasa Hukum Pada Tindakan Diskresi Polisi, Prosiding Konferensi Nasional Ke-4 yang diselenggarakan oleh Asosiasi Program Pascasarjana Perguruan Tinggi Muhammadiyah, Mei 2016, hlm. 241. 
Peneliti melakukan membuat quisioner online melalui aplikasi Google Form yang diisi oleh 20 (dua puluh) Advokat dengan sebaran wilayah pengisian Jakarta-DepokCilegon-Gorontalo-Madura-Jambi-Riau terhadap suatu fenomena kebahasaan dalam proses penyidikan. Peneliti mengajukan pertanyaan "Bagaimanakah cara si Pemeriksa dalam mengajukan pertanyaan tersebut?" Maka, sebanyak 12 (dua belas ) orang atau 60\% (enam puluh prosen) menjawab "Menyudutkan", dan sebanyak 4 (empat) orang atau 20\% (dua puluh prosen) menjawab "Menyatakan ketidakpercayaan terhadap keterangan yang diperiksa", dan sebanyak 4 (empat) orang atau 20\% (dua puluh prosen) menjawab "Menggiring si Terperiksa untuk menjawab sesuai keinginan Pemeriksa". Lihat Diagram berikut:

\section{Bagaimanakah cara si Pemeriksa dalam mengajukan pertanyaan tersebut? 20 tanggapan}

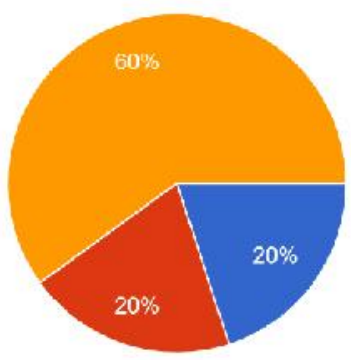

Menyudutkan

Menyatakan ketidakpercayaan terhadap keterangan yang diperiksa

Menggiring si Terperiksa untuk

menjawats sesuai keinginan Pemeriksa

Bagaimana jika hal tersebut terjadi? Dalam quisioner online Peneliti, sebanyak 90\% (sembilan puluh persen) telah mengajukan protes terhadap fenomena kebahasaan dalam peristiwa tuturan tersebut. Namun demikian, Advokat IKS ${ }^{8}$, bahwa Kuasa Hukum seringkali diminta tenang dan seringkali diminta untuk meninggalkan tempat pemeriksaan. Fenomena pengusiran terhadap Advokat dalam melaksanakan fungsi dan tugasnya dalam mendampingi Klien, secara yuridis normatif, tidaklah dapat dikatakan sebagai suatu pelanggaran hukum dari Penyidik. Oleh karena, berbasis kepada Pasal 115 ayat (1) KUHAP menegaskan "Dalam hal penyidik sedang melakukan pemeriksaan terhadap tersangka, penasihat hukum dapat mengikuti jalannya pemeriksaan dengan cara melihat serta-mendengar pemeriksaan." Artinya, fungsi pendampingan yang merupakan implementasi dari profesi Advokat tersebut bersifat pasif.

Padahal, kewajiban seorang Advokat dalam menjalankan profesinya telah secara tegas diatur dalam Pasal 15 Undang-Undang Nomor 18 Tahun 2003 tentang Advokat (UU No. 18/2003) yang menegaskan "Advokat bebas dalam menjalankan tugas profesinya untuk membela perkara yang menjadi tanggung jawabnya dengan tetap berpegang pada kode etik profesi dan peraturan perundang-undangan." Ketentuan tersebut mengandung makna bahwa Advokat dalam menjalankan profesinya harus memperoleh kebebasan berdasarkan fungsinya.

\footnotetext{
${ }^{8}$ Wawancara Tertulis, tanggal 15 April 2009, Responden meminta agar dirahasiakan namanya. IKS merupakan salah satu Advokat dari 6 (enam) orang Advokat yang mengisi Wawancara Tertulis.
} 
Berdasarkan uraian di atas, maka menurut Peneliti menjadi menarik untuk dikaji ulang mengenai pelaksaan fungsi profesi Advokat dalam menjaga ekuilibirium dalam pemeriksaan penyidikan untuk menghasilkan Berita Acara Pemeriksaan (BAP) sebagai dokumen hukum untuk memasuki proses pemeriksaan lebih lanjut dalam Sistem Peradilan Pidana.

Berdasarkan uraian di atas, maka Peneliti mengajukan rumusan masalah sebagai berikut: "Bagaimanakah seharusnya model pendampingan oleh Advokat sebagai Kuasa Hukum dalam mendampingi Kliennya pada proses penyidikan?"

\section{Metode Penelitian}

Metode yang digunakan dalam penelitian ini adalah Metode Yuridis Normatif, sebagai suatu konsekuensi logis dari sifat Ilmu Hukum yang sui generis, dengan menggunakan data sekunder yaitu bahan hukum primer, bahan hukum sekunder, dan bahan hukum sekunder. Namun demikian, Metode Yuridis Normatif memiliki kelemahan yang tidak mampu menjangkau untuk melakukan kajian terhadap fenomena kebahasaan berupa peristiwa tuturan dalam komunikasi. Namun demikian, menurut Johnny Ibrahim, bahwa keuntungan penggunaan Metode Penelitian Yuridis Normatif adalah kebolehan dalam menggunakan berbagai model pendekatan penelitian. ${ }^{9}$ Oleh karena itu, Peneliti menggunakan beberapa model Pendekatan Penelitian yaitu pendekatan filsafat (philosophy approach), pendekatan konseptual (conceptual approach), pendekatan kasus (case approach), dan pendekatan linguistik (linguistic approach), dengan menggunakan model penafsiran semiotika dan pragmatik terhadap fenomena kebahasaan tertetntu yang muncul dalam pemeriksaan penyidikan.

\section{Kerangka Teoretis}

\section{Tindakan Komunikasi Instrumental}

Konsep mengenai 'tindakan komunikasi instrumental' ini, pada hakekatnya, hanya merupakan suatu konsep yang Peneliti pahami secara a contrario dari keseluruhan Paradigma Komunikasi yang dikonstruksikan oleh Jürgen Habermas. Yang digagas oleh Jürgen Habermas adalah 'rasio komunikatif' sebagai basis dari terciptanya suatu praxis komunikatif atau tindakan komunikatif yang bersifat intersubjektif. Artinya, tindakan komunikasi instrumental bukanlah konsep yang dicetuskan oleh Jürgen Habermas, namun justru merupakan kondisi komunikasi yang terjadi dan dikritik oleh Habermas.

Tindakan komunikasi instrumental dengan rasionalitas instrumental adalah suatu rasionalitas yang diarahkan atau bekerja untuk mengejar seefektif mungkin kepentingan diri sendiri, bersifat menominasi dan menghegemoni. Rasionalitas instrumental ini juga

${ }^{9}$ Johnny Ibrahim, Teori dan Metodologi Penelitian Hukum Normatif, (Malang: Bayumedia Publishing, 2012), hlm. 300. 
bersifat monologis, dan juga bertujuan untuk mengontrol. ${ }^{10}$ Dalam hal ini, Habermas menyebutnya sebagai komunikasi dengan tindakan rasional bertujuan atau rasio yang berpusat pada subjek.

Habermas memperlihatkan kelemahan para pendahulunya, karena tidak hanya mengandaikan praxis sebagai kerja, yang disebutnya "tindakan rasional bertujuan", melainkan juga rasional sebagai penaklukan, kekuasaan, atau apa yang disebutnya "rasio yang berpusat pada subjek". Modenisasi kapitalis berjalan timpang karena mengutamakan rasionalisasi dalam bidang subsistem-subsistem tindakan rasionalbertujuan, dan mengesampingkan rasionalisasi di bidang kerangka-kerja institusional atau komunikasi. ${ }^{11}$

Paradigma Komunikasi yang dikonstruksikan oleh Habermas merupakan kritik kepada Karl Marx yang mereduksi makna praxis sebagai kerja. Dalam pandangan Marx, praxis kehidupan manusia adalah kerja. Kerja, bagi Marx, adalah kegiatan indrawi manusia yang bersifat obyektif. Karena itu hubungan-hubungan produksi di dalam masyarakat juga bersifat obyektif, dalam arti relasi-relasi itu independen dari kehendak manusiawi. Totalitas hubungan-hubungan produksi itu membentuk struktur ekonomi masyarakat yang juga obyektif. Dengan menyamakan praxis dengan kerja, Marx secara sangat sederhana telah meredusir syarat-syarat pembebasan sejati umat manusia, yaitu lewat penghapusan pembagian kerja di dalam masyarakat. ${ }^{12}$ Sedangkan, bagai Habermas sendiri, motif kehidupan dalam bermasyarakat adalah komunikasi.

Hardiman menjelaskan, bahwa dalam pandangan Habermas, hukum merupakan kaidah normatif yang dianggap sudah memisahkan diri dari sosio-normatif tradisional (Lebenswelt) dan menjadi sebuah sistem yang mandiri. Sebagai sebuah sistem, hukum memiliki peran fungsional yang penting dalam membangun integrasi sosial. Dan dalam hukum inilah dimungkinkan terjadinya fungsi strategis, sebab memang fungsi hukum adalah sebagai yurisprudensi dan aturan sosial yang bersifat memaksa demi kepentingan bersama. Dalam hal ini hukum menjadi obyektif, sebagaimana dalam positivisme dan bersifat mengikat. Namun, hukum juga memiliki paradigma ganda, yaitu hukum tidak hanya bersifat obyektif, melainkan juga mestinya merupakan kreasi komunal seluruh warga negara. Hukum harus dibangun di atas konsensus yang rasional dan memiliki visi sebagai komponen dari dunia kehidupan. Hukum juga harus menjadi aturan normatif dibangun di atas syarat-syarat validitas yang dapat diuji secara diskursif. Seiring dengan tumbangnya dogmatisme hukum dan kecenderungan otoritarianisme hukum dimasa lalu, maka kini hukum harus mendapatkan legitimasi melalui diskursus rasional. Dalam konteks kapitalisme, hukum harus mengikat dan menjadi jembatan untuk membangun kehidupan bersama di antara sistem ekonomi dan politik yang terkadang 'termanipulasi' oleh rasio instrumental dan strategis sistem kapitalisme modern dan kekuasaan di mana

${ }^{10}$ Radita Gora dan Sandra Olifia, Membangun Paradigma Komunikasi dalam Perspektif Habermas, Jurnal IKOM USNI, Vol. 5, No. 2, 2017, hlm. 77. 97.

${ }^{11}$ F. Budi Hardiman, Menuju Masyarakat Komunikatif, (Yogyakarta: Kanisius, 1993), hlm.

${ }^{12}$ F. Budi Hardiman, Kritik Ideologi. Menyingkap Pertautan Pengetahuan dan Kepentingan Bersama Jürgen Harbermas, (Yogyakarta: Kanisius, 2009), hlm. 78. 
uang dan kuasa menjadi dua unsur kepentingan utama dalam sistem tersebut. Validitas hukum akan tercapai bila paradigma objektivitas dan diskrusus hukum bisa dipadukan. ${ }^{13}$

Sehingga, sebagai lawan dari tindakan komunikasi instrumental adalah tindakan komunikatif-yang dicetuskan oleh Habermas, yang merupakan sebuah interaksi simbolik. Tindakan komunikatif ini diatur dengan norma-norma konsensual mengikat, yang menentukan berbagai harapan timbal balik menyangkut perilaku dan yang dipahami dan diakui sekurang-kurangnya oleh dua subjek yang sedang bertindak (intersubjektif). ${ }^{14}$ Sehingga, dalam tindakan komunikatif ini berlangsung dengan logika dialog, dan berbeda dengan tindakan komunikatif instrumental yang berlangsung dengan logika monolog, oleh karena, rasionalitas yang dikonstruksikan adalah rasionalitas subjek-objek. Dengan demikian, dalam suatu tindakan komunikasi instrumental akan selalu tercipta hubungan yang tidak setara dan seimbang, bahkan terjadi keadaan manipulatif dari subjek kepada objek berdasarkan kepentingan subjek.

\section{Konsep Oposisi Biner (Binary Opposition)}

Konsep Oposisi Biner (Binary Opposition) ini diperkenalkan oleh Jacques Derrida-seorang dekonstruksionis dari Prancis, dalam suatu upayanya untuk membongkar metafisika kehadiran sebagai suatu 'mitos' dalam modernitas yang merupakan warisan dari filsafat barat. Derrida berusaha untuk menunjukan adanya suatu kesadaran palsu yang terkandung dalam metafisika kehadiran tersebut, sebagai sesuatu yang bersifat 'common sense', dan mencoba untuk menggoyang kesadaran tersebut dengan suatu premis bahwa ada makna lain yang disingkirkan sebagai sesuatu 'yang lain' dalam keutuhannya dengan makna 'yang sentral'.

Oposisi biner (binary Opposition) mengandung unsur yang diistimewakan dan unsur lain yang dipinggirkan. Kedua unsur tersebut disusun dengan berdasarkan batasbatas tertentu yang mengakibatkan kedua unsur tersebut menjadi terpisah. Oposisi biner (binary Opposition) adalah inti dari sistem perbedaan (system of difference) yang menjadi dasar pemikiran struktural. Oposisi biner selalu dijadikan landasan pada filsafat barat. Contohnya, kata "penanda" akan dioposisibinerkan dengan kata "petanda" (penanda/petanda), kata "benar" dioposisibinerkan dengan kata "salah" (benar/salah), kata "laki-laki”" dioposisibinerkan dengan "perempuan" (laki-laki/perempuan). ${ }^{15}$ Dengan kata lain, dalam oposisi biner terdapat unsur yang menempatin posisi "yang sentral" dan unsur lainnya dapat dikatakan sebagai unsur "yang lain".

${ }^{13}$ M Taufiq Ridho dan M Nur Prabowo S., Stereotype Dalam Etnisitas Dan Identitas Di Indonesia: Telaah Perspektif Diskursus Rasional Habermas, Journal Islamic Review, Vol. III, No. 1, April 2014, hlm. 105-106.

${ }^{14}$ Thomas McCarthy, Teori Kritis Jürgen Habermas, [Pentj. Nurhadi], (Yogyakarta: Kreasi Wacana, 2006), hlm. 27-28.

${ }^{15}$ Rocky Marbun dan Endra Wijaya, Language, Communication, and Law: Dismantling Binary Opposition in the Pre-Adjudication Sphere, Proceedings of First International Conference on Culture, Education, Linguistics and Literature, CELL 2019, Purwokerto, Central Java, Indonesia, European Alliance for Innovation (EAI) Publisher, 5-6 Agustus 2019, hlm. 5. 
Menurut Christopher Norris, oposisi dalam linguistik ini berjalan berdampingan dengan hal yang sama dalam tradisi filsafat barat. Dalam oposisi biner ini, menurut tradisi filsafat barat, istilah-istilah yang pertama--misalnyamajikan, lebih superior dari yang kedua - misalnya bawahan/karyawan. Istilah-istilah yang kedua tersebut merupakan representasi palsu dari yang pertama atau bersifat inferior. Tradisi ini dinamakannya logosentrisme dan dipergunakan untuk menerangkan asumsi adanya hak istimewa yang disandang istilah pertama dan "pelecehan" terhadap istilah kedua. ${ }^{16}$ Konsep oposisi biner ini merupakan suatu upaya mendekonstruksi "yang sentral", dengan memasukkan unsur "yang lain" ke dalamnya, yang dikenal dengan suatu model penafsiran dekonstruksi oleh Derrida.

Penafsiran dekonstruksi yang dilakukan oleh Derrida, bertujuan membongkar oposisi biner dengan menampilkan dan mempertunjukkan unsur inferior dalam oposisi biner sebagai sesuatu hal yang pula memiliki makna dan nilai yang lain. Menyuarakan suatu unsur "yang lain" dalam suatu oposisi biner, guna menggoyang kemapanan makna dari unsur "yang sentral" dan mencegah terjadinya dominasi makna.

\section{Konsep Sejarah Pengaruh (Wirkungsgeschichte)}

Pada hakekatnya, Peneliti secara sewenang-wenang (arbitrer) untuk memposisikan Wirkungsgeschichte sebagai salah satu konsep dari penelitian ini. Oleh karena, Wirkungsgeschichte itu sendiri merupakan salah satu konsep kunci bagi Hans-Georg Gadamer dalam mengkonstruksikan Hermeneutika Filosofis, yang difungsikan untuk merehabilitasi otoritas dan tradisi.

Wirkungsgeschichte atau sejarah pengaruh yang dimaksud oleh Gadamer adalah secara fungsional untuk memahami sejarah yang tidak hanya sebagai suatu fenomena sejarah, namun memahami pengaruh karya-karya itu di dalam sejarah. ${ }^{17}$ Berkaitan dengan hal tersebut, dalam kaitannya dengan tradisi, maka menurut Gadamer bahwa Bagaimanapun hubungan lazim kita dengan masa silam tidak dicirikan dengan pengambilan jarak dan pembebasan diri kita dari tradisi, melainkan kita senantiasa tersituasi di dalam tradisi-tradisi, dan hal ini bukanlah sebuah proses yang mengobyektivasikan-yaitu kita tidak memahami apa yang dikatakan tradisi sebagai sesuatu yang lain, sesuatu yang asing. Tradisi selalu menjadi bagian kita, sebuah model atau eksemplar, suatu pengakuan diri kita sendiri yang penilaian historis kita nanti akan hampir tidak dapat melihatnya sebagai semacam pengetahuan, melainkan sebagai sebuah ikatan yang paling tulus dengan tradisi. ${ }^{18}$

Menurut Gadamer, bahwa pengetahuan kita, termasuk keseluruhan dalam pengalamandalam kehidupan kita, secara intrinsik dipengaruhi oleh kesejarahan yang kita

\footnotetext{
${ }^{16}$ Christopher Norris, Membongkar Teori Dekonstruksi Jacques Derrida, (Yogyakarta: ArRuzz Media, 2016), hlm. 9.

${ }^{17}$ F. Budi Hardiman, Gadamer Dan Hermeneutika Filosofis, Makalah untuk kuliah terakhir Kelas Filsafat Seni Memahami: Hermeneutika dari Schleiermacher sampai Gadamer, Serambi Salihara, 25 Februari 2014, hlm. 5.

${ }^{18}$ Ibid., hlm. 3.
} 
hidupi di masa lampau kita: baik pengaruhnya tersebut berasaldari gagasan kita sendiri, institusi-institusi, kenyataan dalam kehidupan berpolitik, maupun kehidupan sosioekonomi. Sehingga, tidak perlu diragukan bahwa pengalaman masa lampau kita sangat memberikan pengaruh dalam diri kita guna membuat suatu keputusan kita inginkan dan harapkan, atau bahkan kita takuti di masa depan. ${ }^{19}$

Apabila diteliti secara seksama, maka nampaknya Gadamer menggunakan konsep Wirkungsgeschichte atau sejarah pengaruh untuk mencapai suatu bentuk pemahaman terhadap sesuatu hal yang menjadi objek penelitian. Gadamer memandang bahwa Wirkungsgeschichte atau sejarah pengaruh tersebut, sedikit banyak turut pula mewarnai bagaimana seseorang melakukan interpretasi untuk sebelum mencapai tahap pemahaman.

Menurut Agus Darmaji, bahwa Gadamer juga melihat hubungan reflektif dari sejarah dalam kaitannya dengan pemahaman. Menurutnya, kita senantiasa berusaha untuk memahami, mengritisi, mengasimilasi sesuatu; tapi di sisi lain juga membiarkan pengalaman kita di masa lampau memberikan pengertian tentang diri kita, menempatkan diri kita dalam suatu perspektif tertentu. Jadi, hubungan kedua ini menunjuk pada hubungan reflektif, yang berarti bahwa hubungan antara kesejarahan dan pemahaman dapat bersifat positif dan dapat juga negatif. Hubungan antara aspek kesejarahan dan pemahaman secara intrinsik menuntut suatu praksis tertentu. Gadamer melihat bahwa praksis bukan sesuatu yang eksternal, karena pemahaman sendiri dinilai sebagai suatu tindakan. Sehingga pemahaman itu sendiri pada dasarnya merupakan praksis. Maka di samping pemahaman itu merupakan tindak reflektif, sekaligus juga historis. Memahami berarti menciptakan makna baru atau menafsirkan sedemikian rupa sehingga tindakan semacam ini akhirnya menjadi bagian dari sejarah atau tradisi yang akan diwariskan untuk generasi mendatang. ${ }^{20}$ Artinya, dalam mencapai suatu pemahaman, seseorang sebagai peneliti hendaknya menyadari suatu Wirkungsgeschichte yang menempati posisi sebagai suatu bentuk kesadaran diri akan suatu pra-pemahaman yang sebelumnya tidak disadarinya.

Maka, menurut Gadamer, tidak ada cara lain kecuali menyadari sejarah pengaruh itu. Kondisi yang demikian akan meletakan seorang peneliti pada keadaannya yang cukup rumit, karena kesadaran sejarah pengaruh menjadi berlapis-lapis. Dimana, menurut Jean Grondin, kesadaran akan Wirkungsgeschichte tersebut menjadi 4 (empat) lapisan kesadaran sejarah pengaruh, yaitu lapisan pertama, kesadaran sejarah pengaruh sebagai genetivus objectivus adalah kesadaran peneliti akan ketersituasiannya, akan kenyataan bahwa ia berada di dalam situasi hermeneutis tertentu; lapisan kedua adalah pengertian umum filosofis tentang kesadaran akan bekerjanya atau berpengaruhnya sejarah dan tradisi di dalam setiap pemahaman, sekalipun kita tidak menyadarinya; lapisan ketiga, kesadaran sejarah pengaruh sebagai genetivus subjectivus adalah kesadaran seseorang yang mengambil bagian dalam kesadaran suatu zaman, Zeitgeist, sehingga kita boleh

${ }^{19}$ Hans-Georg Gadamer, Philosophical Hermeneutics, (London: University of California Press, 1976), hlm. 8-9.

${ }^{20}$ Agus Darmaji, Dasar-Dasar Ontologis Pemahaman Hermeneutik Hans-Georg Gadamer,Jurnal Refleksi, Vol. 13, No. 4, April 2013, hlm. 471. 
mengatakan bahwa orang seperti Soekarno, misalnya, adalah anak zamannya; dan lapisan keempat adalah refleksi diri sejarah pengaruh itu sendiri, bukan sebagai klaim atas superioritas, melainkan sebagai kesadaran akan keterbatasannya. ${ }^{21}$

\section{Kerangka Konsepual}

\section{Konsep Hukum Penyidikan}

Penyidikan, memperolah konsep hukumnya, dengan disandarkan kepada Pasal 1 angka 2 KUHAP yang menegaskan "Penyidikan adalah serangkaian tindakan penyidik dalam hal dan menurut cara yang diatur dalam undang-undang ini untuk mencari serta mengumpulkan buktiyang dengan bukti itu membuat terang tentang tindak pidana yang terjadi dan guna menemukan tersangkanya."Dengan demikian, sebenarnya tidak ada lagi pengertian lain selain apa yang telah diformalkan oleh pemegang otoritas. Sehingga, Pasal 1 angka 2 KUHAP tersebut merupakan bahasa hukum yang resmi. Namun demikian, sifat positif yang dilekatkan oleh otoritas tersebut bukan berarti menghentikan setiap ahli hukum untuk memberikan makna. Oleh karena, makna tersebut berada dibelakang kata/simbol kata. Yang harus dijelaskan dan diuraikan baik dalam bentuk tuturan maupun argumentasi tertulis.

Penyidikan sebagai suatu konsep hukum, menurut M. Yahya Harahap, adalah suatu tindakan lanjut dari kegiatan penyelidikan dengan adanya suatu terjadinya peristiwa tindak pidana. Persyaratan dan pembatasan yang ketat dalam penggunaan upaya paksa setelah pengumpulan bukti permulaan yang cukup guna membuat terang suatu peristiwa yang patut diduga merupakan tindak pidana. ${ }^{22}$

Uraian yang diungkapkan oleh M. Yahya Harahap tersebut, memang relatif lebih mendekati konsep hukum yang dianut oleh KUHAP. Adalah benar, bahwa penyidikan merupakan tindakan hukum lanjutan setelah penyelidikan. Suatu penyidikan tidak dapat dilakukan bila dalam proses penyelidikan tidak menemukan bukti-bukti untuk menduga adanya peristiwa pidana. Artinya, peristiwa pidana tersebut baru sebatas asumsi semata, belum muncul validitas kebenaran. Oleh sebab itulah, validitas kebenaran bahwa peristiwa pidana tersebut benar adanya-mengacu kepada pendapat M. Yahya Harahap, ketika Penyidik memiliki keyakinan berdasarkan alat bukti yang dikumpulkan baik dalam proses penyelidikan dan penyidikan. Sehingga, memunculkan kekuasaan dan kewenangan Penyidik untuk melakukan upaya paksa. Upaya paksa tersebut dibatasi dan diperketat setelah melakukan pengumpulan alat bukti dan Penyidik yakin akan alat bukti tersebut.

Berdasarkan uraian di atas, maka dapatlah ditarik suatu kesimpulan bahwa penyidikan adalah suatu proses bekerjanya penyidik guna menindaklanjuti hasil dari penyelidikan dalam mencari, menemukan dan mengumpulkan alat bukti, sehingga muncul keyakinan dalam diri Penyidik bahwa telah terang dan jelas mengenai hakikat

\footnotetext{
${ }^{21}$ F. Budi Hardiman,Gadamer Dan......... Op.cit., hlm. 6.

${ }^{22}$ M. Yahya Harahap, Pembahasan Permasalahan Dan Penerapan KUHAP (Penyidikan dan Penuntutan), (Jakarta: Sinar Grafika, 2003), hlm. 210.
} 
dari suatu perbuatan pidana dan keyakinan atas hal tersebut memberikan hak dan kewenangan bagi Penyidik untuk melakukan dua hal yaitu menetapkan seseorang sebagai tersangka dan sekaligus menentukan upaya paksa.

\section{Advokat Dalam Sistem Peradilan Pidana}

Akar kata advokat, apabila didasarkan pada Kamus Latin-Indonesia dapat ditelusuri dari bahasa Latin yaitu advocates yang berarti antara lain yang membantu seseorang dalam perkara, saksi yang meringankan. ${ }^{23}$ Di dalam Black's Law Dictionary, kata advocate (Inggris) memiliki arti "a person whos assists, defends, pleads, or prosecutes other". ${ }^{24}$ Sedangkan dalam Kamus Besar Bahasa Indonesia (KBBI) online menerangkan "advokat" memiliki makna "ahli hukum yang berwenang sebagai penasihat atau pembela perkara dalam pengadilan; pengacara." 25 Dan menurut English Language Dictionary,Advokat didefinisikan sebagai berikut : "an Advocate is a lawyer who speaks in favour of someone or defends them in a court of law."Artinya, Advokat adalah seorang pengacara yang berbicara atas nama seseorang atau membela mereka di pengadilan. Definisi atau pengertian advokat tersebut menunjukkan bahwa cakupan pekerjaan Advokat dapat meliputi pekerjaan yang berhubungan dengan pengadilan dan pekerjaan diluar pengadilan. ${ }^{26}$

Secara normatif, definisi dan pengertian Advokat terdapat dalam Undang-Undang Nomor 18 Tahun 2003 tentang Advokat (UU No. 18/2003), pada Pasal 1 angka 1 menjelaskan“Advokat adalah orang yang berprofesi memberi jasa hukum, baik di dalam maupun di luar pengadilan yang memenuhi persyaratan berdasarkan ketentuan UndangUndang ini."

Berkaitan dengan pelaksanaan fungsi profesi Advokat tersebut, maka secara normatif, Pasal 54 KUHAP yang menegaskan "Guna kepentingan pembelaan, tersangka atau terdakwa berhak mendapat bantuan hukum dari seorang atau lebih penasihat hukum selama dalam waktu dan pada setiap tingkat pemeriksaan, menurut tata cara yang ditentukan dalam undang-undang ini'.Namun, dalam hal pemeriksaan pada ranah pra-adjudikasi, telah dibatasi oleh Pasal 115 ayat (1) KUHAP menegaskan "Dalam hal penyidik sedang melakukan pemeriksaan terhadap tersangka, penasihat hukum dapat mengikuti jalannya pemeriksaan dengan cara melihat serta mendengar pemeriksaan."

Hal tersebut sebagaimana ditegaskan kembali-berkaitan mengenai mekanisme pendampingan, dalam Penjelasan Pasal 115 ayat (1) KUHAP yang menegaskan "Penasihat hukum mengikuti jalannya pemeriksaan secara pasif'.

\section{Analisis dan Pembahasan}

${ }^{23}$ V. Harlen Sinaga, Dasar-dasar Profesi Advokat, (Jakarta: Erlangga, 2011), hlm. 2.

${ }^{24}$ Bryan A. Garner (Ed), Black's Law Dictionary, 7th Edition, St. Paul, MINN: West Group, 1999, hlm. 56.

${ }^{25} \mathrm{http}: / / \mathrm{kbbi}$.web.id/advokat

${ }^{26}$ V. Harlen Sinaga, Loc.cit. 
Secara skematik, dalam Sistem Peradilan Pidana, Advokat merupakan salah satu subsistem/komponen yang menjalankan fungsi penegakan hukum, yang lepas dari dominasi institusi penegak hukum lain $^{27}$, secara egaliter (setara). Sehingga, seorang Advokat dalam menjalankan hak konstitusionalnya harus berada dalam keadaan bebas dari segala macam bentuk tekanan. Bebas dari segala tekanan tersebut sebagaimana ditegaskan dalam Penjelasan Pasal 14 ayat (1) UU No. 18/2003 bahwa "Yang dimaksud dengan "bebas" adalah tanpa tekanan, ancaman, hambatan, tanpa rasa takut, atau perlakuan yang merendahkan harkat martabat profesi. Kebebasan tersebut dilaksanakan sesuai dengan kode etik profesi dan peraturan perundang-undangan."

Uraian di atas, tentunya memunculkan anomali nilai antara upaya implementasi UU No. 18/2003 dengan KUHAP. Oleh karena, secara normatif, KUHAP memiliki sifat positivistik-legalistik ketika setiap Penyidik dalam melakukan pemeriksaan terhadap Terlapor/Saksi/Tersangka berbasis kepada Pasal 3 KUHAP yang menegaskan "Peradilan dilakukan menurut cara yang diatur dalam undang-undang ini."

Persinggungan antara kedua perundang-undangan tersebut, memunculkan suatu keadaan yang diperkenalkan oleh Derrida sebagai suatu oposisi biner (binary opposition). Dimana, KUHAP dilekatkan sebagai unsur "yang sentral”, sedangkan UU No. 18/2003 sebagai unsur "yang lain".Akibatnya, Penyidik—dalam struktur oposisi biner tersebut, dalam melakukan pemeriksaan-yang berbasis kepada komunikasi, melalui output-nya adalah Berita Acara Pemeriksaan (BAP)—sebagaimana diperintahkan dalam Pasal 8 KUHAP jo Pasal 75 KUHAP, tidaklah bertindak secara egaliter pada komunikasi penyidikan tersebut. Dimana, seharusnya dalam suatu komunikasi kedua belah pihak bertindak sebagai komunikator dan komunikan secara bergantian saling bertukar posisi untuk mencapai suatu pemahaman bersama.

Namun demikian, menurut Sri Waljinah, bahwa model komunikasi yang terjadi dalam ranah penyidikan merupakan upaya pengontrolan kesadaran diri si Terperiksa akan keadaannya yang berada di bawah dominasi Pemeriksa melalui model komunikasi instrumental. Model komunikasi instrumental tersebut merupakan model interogasi yang diajarkan oleh International Criminal Investigative Training Assistance Program (ICITAP).$^{28}$ Artinya, setiap informasi yang diucapkan dalam komunikasi penyidikan tersebut, hanya merupakan bahan keterangan semata.

Model komunikasi penyidikan, pada hakekatnya, telah dibatasi melalui Pasal 117 KUHP yang menegaskan sebagai berikut:

(1) Keterangan tersangka dan atau saksi kepada penyidik diberikan tanpa tekanan dari siapa pun dan atau dalam bentuk apapun;

(2) Dalam hal tersangka memberi keterangan tentang apa yang sebenarnya ia telah lakukan sehubungan dengan tindak pidana yang dipersangkakan kepadanya, penyidik mencatat dalam berita acara seteliti-telitinya sesuai dengan kata yang dipergunakan oleh tersangka sendiri.

\footnotetext{
${ }^{27}$ Pasal 5 ayat (1) UU No. 18/2003

${ }^{28}$ Sri Waljinah, Loc.cit.
} 
Berdasarkan ketentuan di atas, maka komunikasi penyidikan dibatasi terhadap keterangan yang disampaikan oleh si terperiksa atas pertanyaan yang disampaikan oleh Penyidik. Dalam hal ini, Penyidik bertindak sebagai komunikator (penyampai pesan), dan si terperiksa bertindak sebagai komunikan (penerima pesan). Namun pada sisi lain, ketika si terperiksa memperoleh pemahaman atas pesan yang disampaikan tersebut, maka si terperiksa berbalik menjadi komunikator (penyampai pesan) dan Penyidik bertindak sebagai komunikan (penerima pesan). Pesan yang diterima oleh Penyidik-berbasis kepada Pasal 117 ayat (2) KUHAP, hanya memiliki kewajiban menuangkan dalam Berita Acara Pemeriksaan (BAP) yang secara gramatikal atau berdasarkan struktur pesan tersebut. Artinya, Penyidik tidak memiliki kewenangan untuk merubah struktur pesan tersebut secara redaksional.

Penyidik, sebagai suatu unsur "yang sentral", dengan berbasis kepada kekuasaan dan kewenangannya dalam proses pemeriksaan tersebut menutup pintu komunikasi dengan logika dialog. Oleh karena, guna mencapai kepentingan pemeriksaan dengan menggunakan komunikasi instrumental tersebut, yang ada hanya komunikasi dengan logika monolog. Penyidik dapat melakukan manipulasi komunikasi terhadap si terperiksa, sehingga yang terjadi adalah reifikasi (pembendaan) terhadap si terperiksa.

Manipulasi dalam komunikasi tersebut menjadi monolog, ketika pesan (-berupa pertanyaan) yang disampaikan secara lisan kepada si terperiksa, menurut Paul Ricoeur ${ }^{29}$, akan membawa serta aspek intonasi dan gesture dari Penyidik-sebagai komunikator. Pada tataran lebih lanjut, menurut Linda Thomas dan Shan Wareing, suatu sikap akan turut pula bersinggungan dengan fungsi afektif ketika berhubungan dengan bahasa. Dimana, bahasa dalam fungsi afektif tersebut berkaitan dengan kompetensi dan kekuasaan, serta status sosial. ${ }^{30}$ Sehingga, Penyidik dalam komunikasi penyidikan menempati posisi "yang sentral" karena kekuasaan dan status sosialnya. Akibatnya, ide dan gagasan yang terkandung dalam pertanyaan menjadi sepenuhnya kewenangan Penyidik (komunikator awal).

Keadaan komunikasi penyidikan seperti tersebut di atas, oleh M. Syukri Akub dan Baharuddin Baharu, disebut sebagai suatu keadaan yang sangat potensial memunculkan pelanggaran hak asasi manusia. Hal ini bukan saja karena Penyidik mempunyai kewenangan untuk melakukan upaya paksa. Namun, juga dapat dikarenakan adanya kebutuhan bagi penyidik untuk mendapatkan keterangan. ${ }^{31}$ Pendapat dari M. Syukri Akub dan Baharuddin Baharu tersebut, rupanya dikonstruksi dari suatu pengalaman empirik berupa adanya masalah penyiksaan untuk memperoleh keterangan berupa pengakuan bersalah dan tersangka secara paksa. ${ }^{32}$ Namun, pengalaman empirik tersebut hanya berbasis kepada pengamatan inderawi an sich. Sedangkan, pengalaman empirik yang

${ }^{29}$ Paul Ricouer, Filsafat Wacana: Membelah Makna dalam Anatomi Bahasa, (Yogyakarta: IRCiSoD, 2005), hlm. 165.

${ }^{30}$ Linda Thomas \& Shan Wareing, Bahasa, Masyarakat \& Kekuasaan, (Yogyakarta: Pustaka Pelajar, 2007), hlm. 14

${ }^{31}$ M. Syukri Akub \& Baharuddin Baharu, Wawasan Due Proses of Law dalam Sistem Peradilan Pidana, (Yogyakarta: Rangkang Education, 2013), hlm. 87-88.

${ }^{32}$ Ibid., hlm. 88. 
berbasis kepada pengolahan rasionalitas terhadap suatu pola tindak tuturan dari Penyidik-yang bersifat menjerat dan pemaksaan makna, merupakan kelemahan dan seringkali luput dari kajian yuridis normatif.

Pemahaman terhadap suatu asumsi atas potensi munculnya pelanggaran hak asasi manusia tersebut, hendaknya tidak hanya disandarkan kepada pola pemikiran berbasis yuridis normatif semata. Oleh karena, pola kerja yang demikian sudah lebih dahulu ada dalam hukum acara pidana di Indonesia semenjak masih menggunakan HIR melalui implementasi asas inquisatoir ${ }^{33}$. Yang pada akhirnya, asas inquisatoir tersebut telah membudaya dalam pola kerja Penyidik. Maka, hal inilah yang kemudian oleh Gadamer diperkenalkan dalam suatu konsep Sejarah Pengaruh (Wirkungsgeschichte).

Suatu bentuk pengaruh dari wirkungsgeschichte nampak sebagai suatu yang terang benderang, ketika fakta empirik terinderawi. Namun, ketika pengaruh wirkungsgeschichte masuk melalui tindak tuturan, maka Ilmu Hukum yang berbasis kepada logika deduksisilogisme tidak akan mampu memverifikasi hal tersebut. Oleh karena, suatu tindak tuturan termodifikasi dalam komunikasi tidak termasuk memiliki makna sebagai tekanan fisik terhadap terperiksa. Namun demikian, bahasa yang dipergunakan dalam komunikasi penyidikan memunculkan permasalahan yang serius ketika dikaitkan dengan perlindungan hak asasi dari terperiksa.

Sebagaimana dijelaskan oleh Peters, Ruiter, dan Kok, bahwa penggunaan "komunikasi yang mengancam" tersebut diharapkan agar terperiksa berperilaku berdasarkan harapan dari pemeriksa, dengan memunculkan suatu kesadaran semu bertitik tolak dari resiko-resiko yang akan dihadapinya, dan bahkan sampai kepada tahapan munculnya refleksi diri atas apa yang akan diperolehnya melalui tahapan negosiasi berbasis kepada hasil akhir. ${ }^{34}$ Perilaku dalam komunikasi yang mengancam tersebut, telah menempatkan terperiksa sebagai objek kajian dari Penyidik guna mencapai kepentingan penyidikan, atau bahkan kepentingan tersebut masuk dalam ranah pribadi Penyidik itu sendiri ketika, secara semiotik, dikaitkan dengan kepentingan karir, jabatan, dan prestasi.

Tindakan komunikasi instrumental dari Penyidik yang me-reifikasi si terperiksa tersebut, merupakan suatu bentuk kesadaran diri akan keterpengaruhan atas wirkungsgeschicte sebagai suatu genetivus subjetivus. Namun demikian, Penyidik pula terlempar (gowerfen-sein) dalam suatu kesadaran atas wirkungsgeschichte sebagai suatu genetivus objektivus, dan tak mampu melepaskan dirinya dalam ketersituasian tersebut. Oleh karena itulah, pembentuk undang-undang pada UU No. 18/2003, pada hakekatnya, menyadari ketersituasian tersebut dengan memberikan kewenangan khusus kepada

${ }^{33}$ Asas inquisatoir berarti tersangka dipandang sebagai objek pemeriksaan, bahwa pengakuan tersangka merupakan bukti terpenting. Sesuai hak-hak asasi manusia yang menjadi ketentuan universal, asas inquisatoirtelah ditinggalkan banyak negeri yang beradab. Lihat: Didik Endro Purwoleksono, Laporan kegiatan Tim Naskah Akademik RUU tentang Hukum Acara Pidana, (Jakarta: BPHN, 2010), hlm. 24.

${ }^{34}$ Gjalt-Jorn Y.Peters, Robert A. C. Ruiter, dan GerjoKok, Threatening Communication: A Qualitative Study of Fear Appeal Effectiveness Beliefs among Intervention Developers, Policymakers, Politicians, Scientists, and Advertising Professionals, International Journal of Psychology, Vol. 49, No. 2, 2014, hlm. 77. 
profesi Advokat untuk menjalankan fungsinya tanpa adanya ancaman kebebasan yang dimilikinya.

Berdasarkan UU No. 18/2003, eksistensi dari profesi Advokat merupakan suatu wujud dari politik hukum negara yang berusaha untuk mewujudkan prinsip-prinsip negara hukum dalam kehidupan bermasyarakat dan bernegara, peran dan fungsi Advokat sebagai profesi yang bebas, mandiri dan bertanggung jawab merupakan hal yang penting, di samping lembaga peradilan dan instansi penegak hukum seperti kepolisian dan kejaksaan. Melalui jasa hukum yang diberikan, Advokat menjalankan tugas profesinya demi tegaknya keadilan berdasarkan hukum untuk kepentingan masyarakat pencari keadilan, termasuk usaha memberdayakan masyarakat dalam menyadari hak-hak fundamental mereka di depan hukum. Advokat sebagai salah satu unsur sistem peradilan merupakan salah satu pilar dalam menegakkan supremasi hukum dan hak asasi manusia. ${ }^{35}$ Artinya, eksistensi Advokat merupakan penyeimbang keadaan dalam proses peradilan pidana guna menjamin terwujudnya supremasi hukum tersebut.

Apabila mengacu kepada model tindakan komunikasi instrumental yang dilakukan oleh Penyidik sebagai upaya untuk me-reifikasi terperiksa, maka kehadiran seorang Advokat yang mendapat amanah untuk mendampingi Kliennya, merupakan pula suatu upaya untuk menjaga hak asasi dari si terperiksa. Eksistensi seorang Advokat tersebut guna menjaga keutuhan dari hak yang dimiliki oleh seseorang dalam memberikan keterangan berdasarkan Pasal 52 KUHAP yang menegaskan "Dalam pemeriksaan pada tingkat penyidikan dan pengadilan, tersangka atau terdakwa berhak memberikan keterangan secara bebas kepada penyidik atau hakim."

Pendampingan terhadap Klien dalam memberikan keterangan tersebut harus dilakukan dengan cara-cara yang tanpa mengajukan pertanyaan dalam komunikasi penyidikan yang tidak bersifat menjerat. Sebagaimana ditegaskan dalam Penjelasan Pasal 166 KUHAP bahwa dalam pemeriksaan penyidik atau penuntut umum tidak boleh mengadakan tekanan yang bagaimanapun caranya.

Namun demikian, eksistensi Advokat untuk menjaga Kliennya dari suatu pertanyaan yang bersifat menjerat terhalangi oleh Pasal 115 ayat (1) KUHAP yang menginginkan proses pendampingan tersebut dilaksanakan secara pasif. Sehingga, berbasis kepada quisioner online dan wawancara tertulis tersebut di atas, tidaklah mengherankan ketika Advokat melaksanakan proses pendampingan secara aktif, akan mendapatkan teguran, bahkan mendapatkan perlakuan dari Penyidik berupa perintah untuk meninggalkan ruangan.

Dengan demikian, seorang Advokat—berbasis kepada Pasal 115 ayat (1) KUHAP, merupakan oposisi biner "yang lain" ketika melakukan pendampingan. Oleh karena itu, dalam konsep oposisi biner diperlukan upaya mendekonstruksi profesi Advokat agar didengarkan makna eksistensinya dalam proses pendampingan.

\section{Penutup}

${ }^{35}$ Penjelasan Umum UU No. 18/2003 


\section{Simpulan}

Kehadiran Advokat sebagai sesuatu yang "Ada" dalam proses pemeriksaan penyidikan merupakan oposisi biner "yang lain", telah mengalami pelecehan makna. Kehadirannya tidak mampu memberikan warna dalam proses terjaminnya hak asasi seseorang pada proses penyidikan. Penyidik yang merupakan oposisi biner "yang sentral" secara afektif —dalam hal penggunaan bahasa untuk komunikasi, akan bertindak arbitrer guna mencapai tujuan dari hal-hal yang telah terkonsepsikan dalam alam pemikirannya. Sehingga, Penyidik melakukan eksternalisasi secara normatif terhadap ungkapanungkapan dari unsur "yang lain" tersebut.

Berdasarkan amanah dari Konsideran Menimbang huruf 'c' KUHAP, yang memfungsikan KUHAP sebagai pedoman bagi penegak hukum dalam bersikap, serta mengacu kepada norma hukum Pasal 52 KUHAP jo Pasal 117 KUHAP jo Pasal 166 KUHAP, maka, keberadaan seorang Advokat dalam menjalankan profesinya perlulah diperkuat guna menyeimbangkan sikap afektif dalam komunikasi penyidikan. Sehingga, Advokat dalam menjalankan profesinya mampu secara maksimal menjaga terwujudnya supremasi hukum.

\section{Saran}

Berdasarkan uraian dalam kesimpulan di atas, maka perlulah kiranya untuk merevisi Pasal 115 ayat (1) KUHAP dan/atau menghapusnya. Pasal 115 ayat (1) KUHAP menegaskan "Dalam hal penyidik sedang melakukan pemeriksaan terhadap tersangka, penasihat hukum dapat mengikuti jalannya pemeriksaan dengan cara melihat serta mendengar pemeriksaan.", maka guna menjaga komunikasi yang dialogis, frasa ".....dengan cara melihat serta mendengar pemeriksaan" harus dihapuskan. Sehingga, Advokat dalam menjalankan profesinya dapat bertindak secara aktif untuk menghindari bentuk-bentuk penekanan terhadap terperiksa.

\section{Daftar Pustaka}

\section{Buku}

Akub,M. Syukri,\& Baharuddin Baharu, Wawasan Due Proses of Law dalam Sistem Peradilan Pidana, Yogyakarta: Rangkang Education, 2013.

Chaer, Abdul, dan Leonie Agustina, Sosiolingugistik, Jakarta: Rineka Cipta, 2010.

Gadamer, Hans-Georg,Philosophical Hermeneutics, London: University of California Press, 1976.

Garner, Bryan A., (Ed), Black's Law Dictionary, 7th Edition, St. Paul, MINN: West Group, 1999. 
Harahap, M. Yahya,Pembahasan Permasalahan Dan Penerapan KUHAP (Penyidikan dan Penuntutan), Jakarta: Sinar Grafika, 2003.

Hardiman, F. Budi,Kritik Ideologi. Menyingkap Pertautan Pengetahuan dan Kepentingan Bersama Jürgen Harbermas, Yogyakarta: Kanisius, 2009. ,Menuju Masyarakat Komunikatif, Yogyakarta: Kanisius, 1993.

Ibrahim, Johnny,Teori dan Metodologi Penelitian Hukum Normatif, Malang: Bayumedia Publishing, 2012.

McCarthy, Thomas,Teori Kritis Jürgen Habermas, [Pentj. Nurhadi], Yogyakarta: Kreasi Wacana, 2006.

Norris, Christopher,Membongkar Teori Dekonstruksi Jacques Derrida, Yogyakarta: ArRuzz Media, 2016.

Purwoleksono, Didik Endro,Laporan kegiatan Tim Naskah Akademik RUU tentang Hukum Acara Pidana, Jakarta: BPHN, 2010.

Ricouer, Paul,Filsafat Wacana: Membelah Makna dalam Anatomi Bahasa, Yogyakarta: IRCiSoD, 2005.

Saleh, Roeslan,Mengadili Sebagai Pergulatan Kemanusiaan, Jakarta: Aksara Baru, 1983.

Sinaga, V. Harlen,Dasar-dasar Profesi Advokat, Jakarta: Erlangga, 2011.

Sofyan, Andi,Hukum Acara Pidana. Suatu Pengantar, Yogyakarta: Rangkang Education, 2012.

Thomas, Linda,\& Shan Wareing, Bahasa, Masyarakat \& Kekuasaan, Yogyakarta: Pustaka Pelajar, 2007.

Wahyono, Padmo,Indonesia Negara Berdasarkan Atas Hukum, Jakarta: Ghalia Indonesia, 1986. 1991. ,Membudayakan Undang-Undang Dasar 1945, Jakarta: Ind-HILL.co,

\section{Artikel}

Darmaji, Agus,Dasar-Dasar Ontologis Pemahaman Hermeneutik Hans-Georg Gadamer,Jurnal Refleksi, Vol. 13, No. 4, April 2013.

Falasifah, Umi, Bambang Dwi Baskoro, dan Sukinta, Tinjauan Tentang Pembaharuan KUHAP Sebagai Landasan Bekerjanya Sistem Peradilan Pidana di Indonesia, Diponegoro Law Journal, Vol. 5, No. 3, 2016.

Gora, Radita, dan Sandra Olifia, Membangun Paradigma Komunikasi dalam Perspektif Habermas, Jurnal IKOM USNI, Vol. 5, No. 2, 2017. 
Hardiman, F. Budi,Gadamer Dan Hermeneutika Filosofis, Makalah untuk kuliah terakhir Kelas Filsafat Seni Memahami: Hermeneutika dari Schleiermacher sampai Gadamer, Serambi Salihara, 25 Februari 2014.

Marbun, Rocky, dan Endra Wijaya, Language, Communication, and Law: Dismantling Binary Opposition in the Pre-Adjudication Sphere, Proceedings of First International Conference on Culture, Education, Linguistics and Literature, CELL 2019, Purwokerto, Central Java, Indonesia, European Alliance for Innovation (EAI) Publisher, 5-6 Agustus 2019.

Ridho,M. Taufiq,dan M. Nur Prabowo S., Stereotype Dalam Etnisitas Dan Identitas Di Indonesia: Telaah Perspektif Diskursus Rasional Habermas, Journal Islamic Review, Vol. III, No. 1, April 2014.

Rumokoy, Nike K.,Eksistensi Afdoening Buiten Process Dalam Hukum Acara Pidana Indonesia, Jurnal Hukum Unsrat, Vol. 23, No. 8, Januari 2017

Waljinah, Sri,Linguistik Forensik Interogasi: Kajian Makna Simbolik Bahasa Hukum Pada Tindakan Diskresi Polisi, Prosiding Konferensi Nasional Ke-4 yang diselenggarakan oleh Asosiasi Program Pascasarjana Perguruan Tinggi Muhammadiyah, Mei 2016.

\section{Internet}

http://kbbi.web.id/advokat

\section{Wawancara}

Wawancara Tertulis, tanggal 15 April 2009.

\section{Undang-Undang}

Undang-Undang Dasar Negara Republik Indonesia Tahun 1945

Undang-Undang Nomor 8 Tahun 1981 tentang Hukum Acara Pidana

Undang-Undang Nomor 18 Tahun 2003 tentang Advokat 